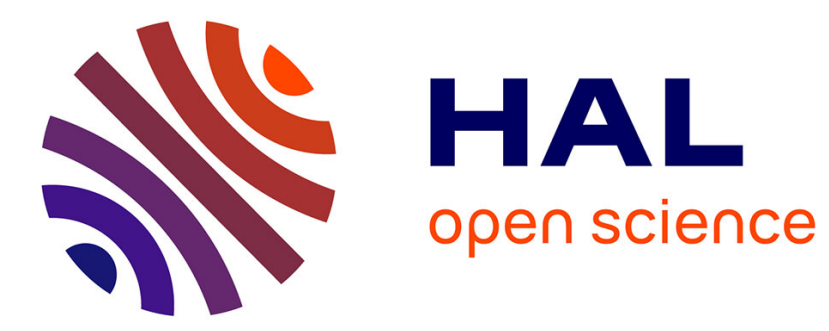

\title{
Fukuyama Cross-Coupling Approach to Isoprekinamycin: Discovery of the Highly Active and Bench-Stable Palladium Precatalyst POxAP
}

\author{
Shuang-Qi Tang, Jacques Bricard, Martine Schmitt, Frédéric Bihel
}

\section{To cite this version:}

Shuang-Qi Tang, Jacques Bricard, Martine Schmitt, Frédéric Bihel. Fukuyama Cross-Coupling Approach to Isoprekinamycin: Discovery of the Highly Active and Bench-Stable Palladium Precatalyst POxAP. Organic Letters, 2019, 21 (3), pp.844-848. 10.1021/acs.orglett.9b00031 . hal-02323246

\author{
HAL Id: hal-02323246 \\ https://hal.science/hal-02323246
}

Submitted on 20 Nov 2020

HAL is a multi-disciplinary open access archive for the deposit and dissemination of scientific research documents, whether they are published or not. The documents may come from teaching and research institutions in France or abroad, or from public or private research centers.
L'archive ouverte pluridisciplinaire HAL, est destinée au dépôt et à la diffusion de documents scientifiques de niveau recherche, publiés ou non, émanant des établissements d'enseignement et de recherche français ou étrangers, des laboratoires publics ou privés. 


\title{
Fukuyama Cross-Coupling Approach to Isoprekinamycin: Discovery of the Highly Active and Bench Stable Palladium Precatalyst POxAP
}

\author{
Shuang-Qi Tang, Jacques Bricard, Martine Schmitt, and Frédéric Bihel*
}

Laboratoire d'Innovation Thérapeutique, Faculté de Pharmacie, UMR7200 CNRS, Université de Strasbourg, 74 Route du Rhin, 67412 Illkirch, France

Supporting Information Placeholder

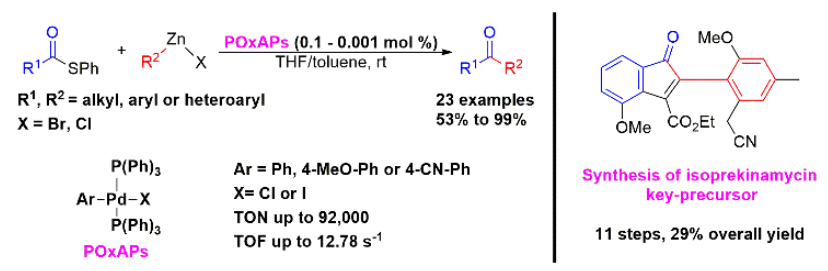

ABSTRACT: An efficient and user-friendly palladium(II) precatalyst, POxAP (Post-Oxidative-Addition Precatalyst), was identified for use in Fukuyama cross-coupling reactions. Suitable for storage under air, the POxAP precatalyst allowed the reaction between thioesters and organozinc reagents with turnover numbers of $\approx 90,000$. A series of 23 ketones were obtained with yields ranging from 53 to $99 \%$. As proof of efficacy, an alternative approach was developed for the synthesis of a key-precursor of the natural product isoprekinamycin.

Benzo[a]fluorenes, including isoprekinamycin (IPK) and fluostatins $A-Q$, represent an interesting class of natural products. ${ }^{1}$ IPK is particularly noteworthy as it bears a diazo group at the 5-position, which plays a crucial role in its cytotoxicity against cancer cell lines. ${ }^{2}$ To date, only one total synthesis of IPK has been reported (Figure 1), ${ }^{2 \mathrm{e}}$ where the key step involved formation of precursor $\mathbf{1}$ through a Suzuki-Miyaura cross-coupling reaction (CCR). While the transformation of 1 into IPK was efficiently achieved over 9 steps and in a $23 \%$ overall yield, the synthesis of $\mathbf{1}$ appeared less efficient, with 16 steps being required to give an overall yield of $3 \%$. Thus, we herein propose an alternative approach based on the Fukuyama cross-coupling reaction, ${ }^{3}$ where a palladium precatalyst POxAP, of generic formula $\mathrm{PdX}(\mathrm{Ar})\left(\mathrm{PPh}_{3}\right)_{2}$ is employed to efficiently generate ketones.

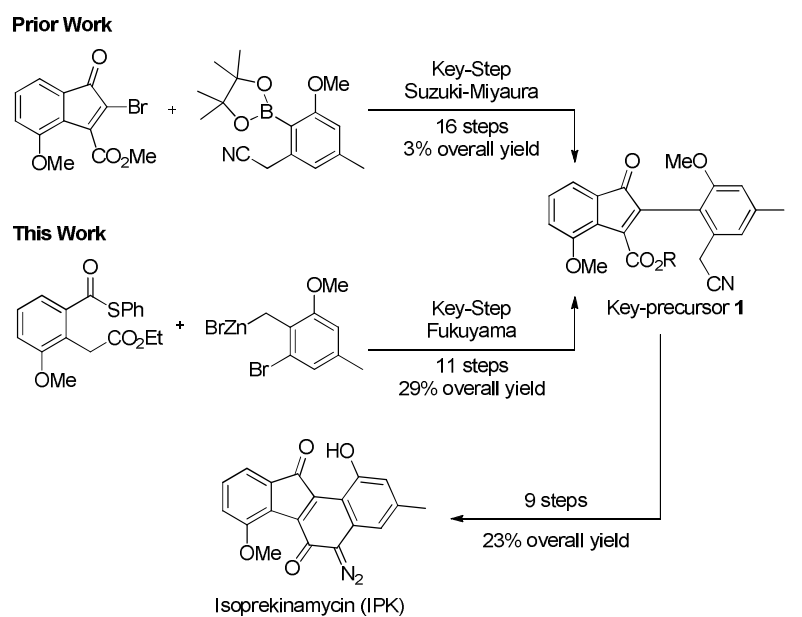

Figure 1. Synthetic strategies to the key IPK precursor
Table 1. Fukuyama CCR on a model system

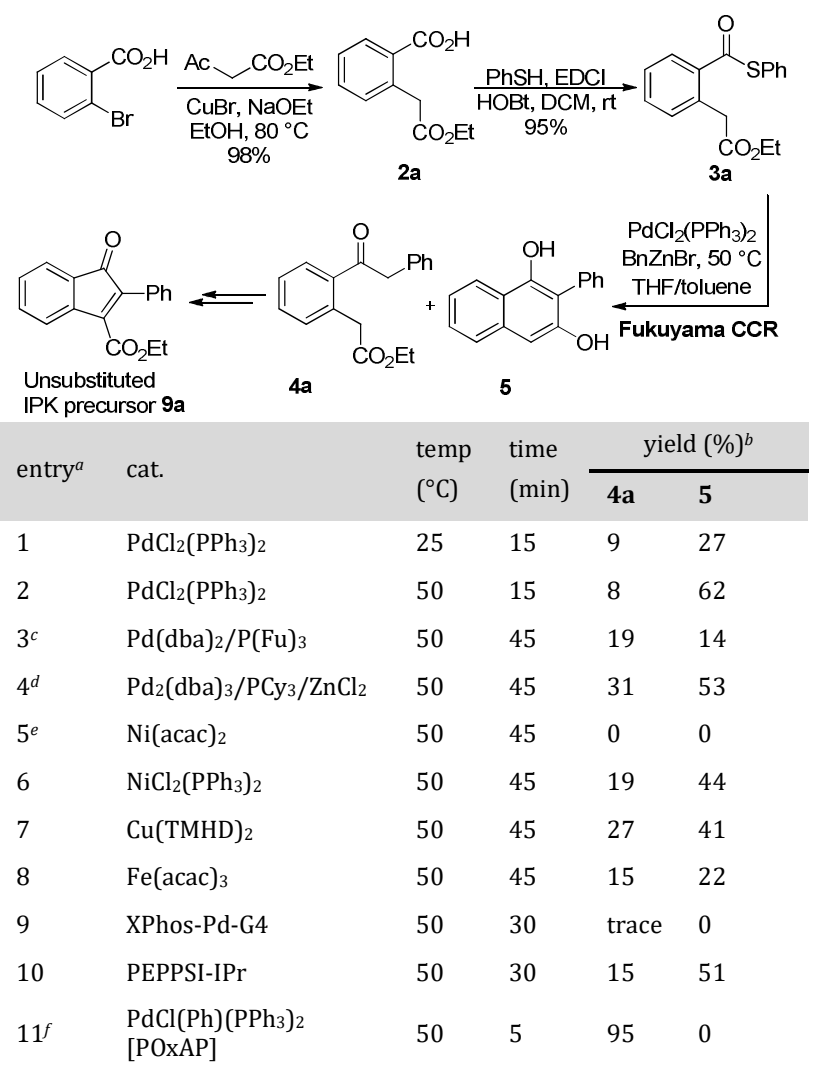

${ }^{a}$ Reaction conditions: Thioester 3a $(0.14 \mathrm{mmol})$, catalyst (1 mol \%), BnZnBr (0.21 mmol, $0.82 \mathrm{M}$ in THF), toluene $(0.26 \mathrm{~mL}), \mathrm{rt}^{b}{ }^{b}$ ssolated yield. $c 1.4 \mathrm{~mol} \% \mathrm{P}(\mathrm{Fu})_{3} .{ }^{d} 2 \mathrm{~mol} \% \mathrm{PCy}_{3}$ and 1 equiv $\mathrm{ZnCl}_{2}$ were used. $e 10 \mathrm{~mol} \% \mathrm{Ni}(\mathrm{acac})_{2}$. $f 0.1 \mathrm{~mol} \%$ 
$\mathrm{PdCl}(\mathrm{Ph})\left(\mathrm{PPh}_{3}\right)_{2}\left(0.1 \mathrm{~mL}, 1.4 \times 10^{-3} \mathrm{M}\right.$ in THF/toluene $)$ was used.

Initially, we investigated the preparation of an unsubstituted version of the key precursor of IPK, as outlined in Table 1 . Starting from commercially available 2 -bromobenzoic acid, a copper-mediated acetylation was easily performed to obtain $2 \mathbf{a}$ in $98 \%$ yield. ${ }^{4}$ A coupling reaction with EDCI/HOBt led to thioester 3a, a classical substrate of the Fukuyama reaction. Surprisingly, under standard conditions, the Fukuyama reaction between $\mathbf{3 a}$ and benzylzinc bromide afforded the expected compound $\mathbf{4 a}$ in a poor $8 \%$ yield (Table 1, entry 2), while naphthalenediol 5 was recovered as the main product ( $62 \%$ yield). A dropwise addition of benzylzinc bromide at $25^{\circ} \mathrm{C}$ still gave a mixture of $4 a$ and 5 in yields of $9 \%$ and $27 \%$, respectively (Table 1, entry 1). It was therefore considered that the Fukuyama reaction was relatively slow, thereby allowing any unreacted $\mathrm{BnZnBr}$ to act as a base toward ketone $\mathbf{4 a}$, speeding up the Dieckman condensation reaction and yielding compound $\mathbf{5}$. Consequently, other catalytic conditions described previously in the literature were investigated for the Fukuyama CCR, with palladium, nickel, and iron-based catalysts being employed in the presence of various ligands or additives (Table 1, entries 3-8). ${ }^{5}$ All conditions favored the formation of $\mathbf{5}$, which we expect may be due to the slow formation of $\operatorname{Pd}(0)$ from $\mathrm{Pd}(\mathrm{II})$. Indeed, during the past decade, significant effort has been focused on the development of stable Pd(II) precatalysts, which can be easily transformed in situ into $\mathrm{Pd}(0) .{ }^{6}$ In the Fukuyama CCR, $4^{\text {th }}$ generation palladacycles from Buchwald's group led to traces of $\mathbf{4 a}$, while PEPPSI-IPr precatalyst from Organ's group afforded ketone 4 a in a 15\% yield (Table 1, entries 9-10). It is important to highlight that these two precatalysts have been optimized for the Negishi $\mathrm{CCR},{ }^{7}$ and may require different ligands for Fukuyama CCR. We then examined an alternative palladium precatalyst, $\mathrm{PdCl}(\mathrm{Ph})\left(\mathrm{PPh}_{3}\right)_{2}$, which we recently identified and referred to by a generic name, POxAP (i.e., a Post-Oxidative-Addition Precatalyst). Indeed, $\mathrm{PdX}(\mathrm{Ar})\left(\mathrm{PPh}_{3}\right)_{2}$ precatalysts respect the criteria of Pd-based OACs (oxidative addition complexes) recently described by Ingoglia and Buchwald. ${ }^{8}$ This palladium complex is well-known in the literature, as it is formed through the first oxidative addition between $\mathrm{Pd}(0) \mathrm{Ln}$ and $\mathrm{PhCl}$, and is common in the majority of palladium-catalyzed CCRs. ${ }^{9}$ While this complex has been extensively cited in various mechanistic studies, it has been scarcely described per se as a catalyst. We have only found three papers published in the seventies, at the very beginning of the palladium-catalyzed CCR era, in which $\mathrm{PdI}(\mathrm{Ph})\left(\mathrm{PPh}_{3}\right)_{2}$ was used in only one example of Heck CCR, ${ }^{10}$ and Negishi CCR. ${ }^{11}$ In 1976, Sekiya and Ishikawa reported that $\mathrm{PdI}(\mathrm{Ph})\left(\mathrm{PPh}_{3}\right)_{2}$ could be used as a catalyst in the $\mathrm{Ku}-$ mada CCR between ArI and $\mathrm{ArMgX}$, with yields ranging from 32 to $82 \%{ }^{12}$ Yet, $\mathrm{PdCl}(\mathrm{Ph})\left(\mathrm{PPh}_{3}\right)_{2}$ complex is a bench stable $\mathrm{Pd}(\mathrm{II})$ complex, that can be both stored and manipulated under air, and is easily obtained from $\mathrm{Pd}\left(\mathrm{PPh}_{3}\right)_{4}{ }^{13}$ In the presence of an organozinc reagent $\mathrm{R}^{1} \mathrm{ZnX}$, this complex follows a Negishi-like initiation step, and provides $\mathrm{PhR}$ as well as a reactive $\mathrm{Pd}(0)$ entity, which is then available for a subsequent Fukuyama catalytic cycle (Figure 2).

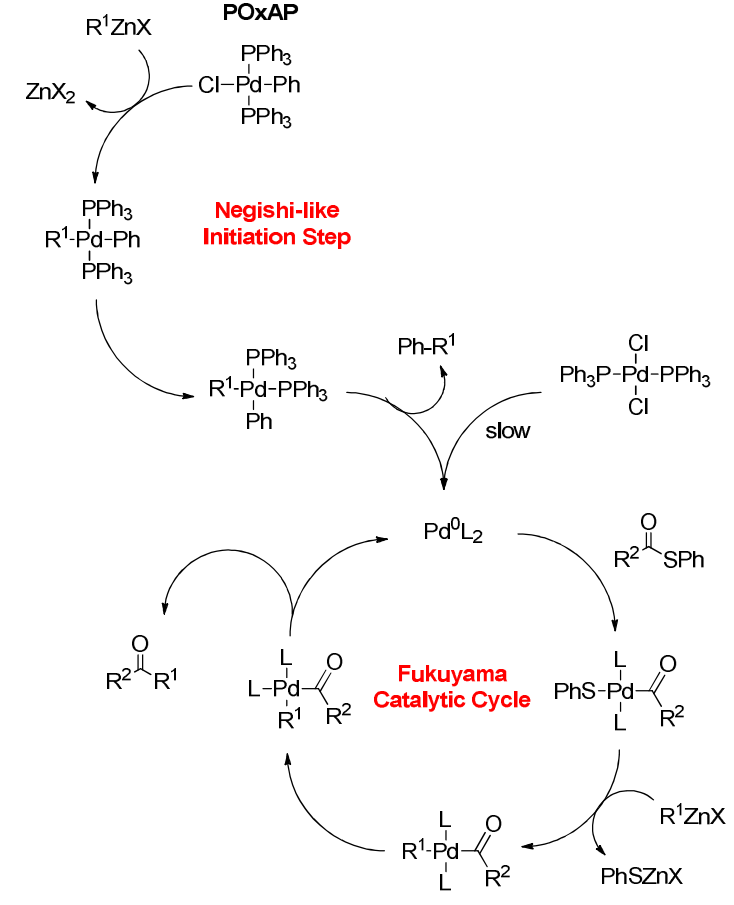

Figure 2. Comparison of the reaction mechanisms involved where $\mathrm{PdCl}_{2}\left(\mathrm{PPh}_{3}\right)_{2}$ and the POxAP $\mathrm{PdCl}(\mathrm{Ph})\left(\mathrm{PPh}_{3}\right)_{2}$ are employed

Thus, using Flemming's procedure, $\mathrm{PdCl}(\mathrm{Ph})\left(\mathrm{PPh}_{3}\right)_{2}$ was obtained in a high yield, and was employed with a loading of $0.1 \mathrm{~mol} \%$ in the Fukuyama CCR featured in Table 1. Pleasingly, ketone 4 a was obtained in a $95 \%$ yield after only 5 min, without any trace of naphthalenediol 5 being observed (Table 1, entry 11). To better determine the reactivity of this new precatalyst, we synthesized 3 derivatives, namely ( $\mathrm{PdCl}(4-\mathrm{CN}-\mathrm{Ph})\left(\mathrm{PPh}_{3}\right)_{2}, \mathrm{PdCl}(4-\mathrm{MeO}-\mathrm{Ph})\left(\mathrm{PPh}_{3}\right)_{2}$, and $\left.\mathrm{PdI}(4-\mathrm{MeO}-\mathrm{Ph})\left(\mathrm{PPh}_{3}\right)_{2}\right)$, in which electron-donating or withdrawing groups were added to the phenyl ring, or where chlorine was substituted with iodine. These potential POxAPs were compared in a kinetic study based on the Fukuyama CCR, as shown in Table 2. Interestingly, with a loading of only $0.001 \mathrm{~mol} \%, \mathrm{PdCl}(\mathrm{Ph})\left(\mathrm{PPh}_{3}\right)_{2}$ catalyzed the formation of ketone $\mathbf{4 b}$ in a $92 \%$ yield with a turnover number (TON) of 92,000 (Table 2, entry 2). In comparison, classical $\mathrm{PdCl}_{2}\left(\mathrm{PPh}_{3}\right)_{2}$ led to a poor yield of $12 \%$ (Table 2 , entry 1 ), while other POxAPs gave similar yields and TONs to $\mathrm{PdCl}(\mathrm{Ph})\left(\mathrm{PPh}_{3}\right)_{2}$ (Table 2, entries 3-5). However, differences in reactivity appeared when measuring the turnover frequencies (TOF). Initial rates were determined for the first $30 \mathrm{~min}$ of the reaction, and it was found that the presence of an aryl moiety bearing an electron-withdrawing group (i.e., 4-CN-Ph, 2.22 vs $5.55 \mathrm{~s}^{-1}$ for $\mathrm{Ph}$ ) decreased the initial rate, while the presence of an electron-donating group (i.e., 4-OMe-Ph, 8.89 vs $5.55 \mathrm{~s}^{-1}$ for $\mathrm{Ph}$ ) increased this rate (Table 2, entries $3-5$ ). This result is fully consistent with our proposed mechanism. Indeed, compared with electron-poor compounds, reductive elimination is favored by electron-rich compounds. Furthermore, the replacement of chlorine by iodine led also to an initial rate increase (i.e., $8.89 \mathrm{vs} 12.8 \mathrm{~s}^{-1}$ ) as iodine is more easily substituted by the organozinc reagent than chlorine (Table 2, entries 4-5). However, these differences in the initial rates disappeared 
between 4 and $8 \mathrm{~h}$ (i.e., the cruising rate), where rates ranging from 1.46 to $1.6 \mathrm{~s}^{-1}$ were recorded. Indeed, following our concept, all four POxAPs led to the same catalytic entity $\mathrm{Pd}(0) \mathrm{Ln}$, which is consistent with observation of similar cruising rates following the initial stages of the reaction.

Table 2. Kinetic study ${ }^{a}$ into the Fukuyama CCR using various precatalysts of generic formula $\mathrm{PdX}(\mathrm{Ar})\left(\mathrm{PPh}_{3}\right)_{2}$

\begin{tabular}{|c|c|c|c|c|c|}
\hline & $3 \mathbf{b}$ & & & $4 b$ & \\
\hline \multirow[b]{2}{*}{ entry } & \multirow{2}{*}{$\begin{array}{l}\text { cat. or POxAP } \\
(0.001 \mathrm{~mol} \%)\end{array}$} & \multirow[b]{2}{*}{ TON } & \multicolumn{2}{|c|}{ TOF $\left(\mathrm{s}^{-1}\right)$} & \multirow{2}{*}{$\begin{array}{l}\text { yield } \\
(\%)^{d}\end{array}$} \\
\hline & & & $\begin{array}{l}\text { initial } \\
\text { rate }^{b}\end{array}$ & $\begin{array}{l}\text { cruising } \\
\text { rate }^{c}\end{array}$ & \\
\hline 1 & $\mathrm{PdCl}_{2}\left(\mathrm{PPh}_{3}\right)_{2}$ & 12,000 & 0.55 & 0.21 & 12 \\
\hline 2 & $\mathrm{PdCl}(\mathrm{Ph})\left(\mathrm{PPh}_{3}\right)_{2}$ & 92,000 & 5.55 & 1.46 & 92 \\
\hline 3 & $\mathrm{PdCl}(4-\mathrm{CN}-\mathrm{Ph})\left(\mathrm{PPh}_{3}\right)_{2}$ & 83,000 & 2.22 & 1.53 & 83 \\
\hline 4 & $\mathrm{PdCl}(4-\mathrm{MeO}-\mathrm{Ph})\left(\mathrm{PPh}_{3}\right)_{2}$ & 89,000 & 8.89 & 1.60 & 89 \\
\hline 5 & $\mathrm{PdI}(4-\mathrm{MeO}-\mathrm{Ph})\left(\mathrm{PPh}_{3}\right)_{2}$ & 91,000 & 12.78 & 1.53 & 91 \\
\hline
\end{tabular}

$a$ Reaction conditions: Thioester $\mathbf{3 b} \quad(0.14 \mathrm{mmol}), \quad[\mathrm{Pd}]$ (0.001 mol \%), BnZnBr (0.21 mmol, 0.82 M in THF), toluene $(0.26 \mathrm{~mL})$, rt. $^{b}$ Initial rate was measured between 0 and $30 \mathrm{~min}$. ${ }^{c}$ Cruising rate was measured between 4 and $8 \mathrm{~h}$. ${ }^{d}$ Yield of $\mathbf{4 b}$ was determined from the average of two independent experiments by HPLC/UV using caffeine as an internal standard.

Further proof of the proposed mechanism shown in Figure 2 is the fact that 3 -phenylpyridine $\left(\mathrm{Ph}-\mathrm{R}^{1}\right)$ was detected by mass spectroscopy, which resulted from the Negishi-like initiation step in the presence of pyridin-3-ylzinc bromide. All POxAPs were bench-stable for several weeks, and could be both manipulated and stored under air.

Metal-catalyzed formation of ketones is still a very prolific area of scientific investigation, ${ }^{14}$ as ketone-containing products are numerous in many fields of chemistry.

Using $\mathrm{PdCl}(\mathrm{Ph})\left(\mathrm{PPh}_{3}\right)_{2}$, we then investigated the scope of the Fukuyama CCR at the $1 \mathrm{mmol}$ scale, synthesizing $23 \mathrm{ke}-$ tones in yields ranging from 53 to $99 \%$ (Scheme 1). As shown, aryl, heteroaryl, and alkyl thioesters were easily coupled to aryl or alkyl organozinc reagents in high yields. Even bulky ketone $\mathbf{4 k}$ was obtained in $82 \%$ yield despite the steric hindrance on both the thioester and the organozinc reagent. In addition, the use of $0.1 \mathrm{~mol} \% \mathrm{PdCl}(\mathrm{Ph})\left(\mathrm{PPh}_{3}\right)_{2}$ produced a range of ketones over 1-3 $\mathrm{h}$ at room temperature. Furthermore, with a 0.001 mol \% loading of PdI(4$\mathrm{MeO}-\mathrm{Ph})\left(\mathrm{PPh}_{3}\right)_{2}$, an extended reaction time of $36 \mathrm{~h}$ transformed $10 \mathrm{mmol}$ of thioester $\mathbf{3 b}$ into the corresponding ketone $\mathbf{4 b}$ in $96 \%$ yield (Scheme $2 \mathrm{a}$ ). 
Scheme 1. Scope of the Fukuyama $\mathrm{CCR}^{a}$ using POxAP PdCl(Ph) $\left(\mathrm{PPh}_{3}\right)_{2}$

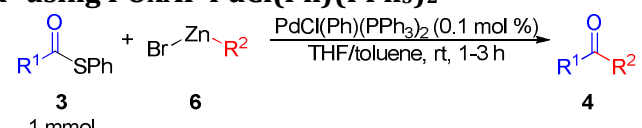

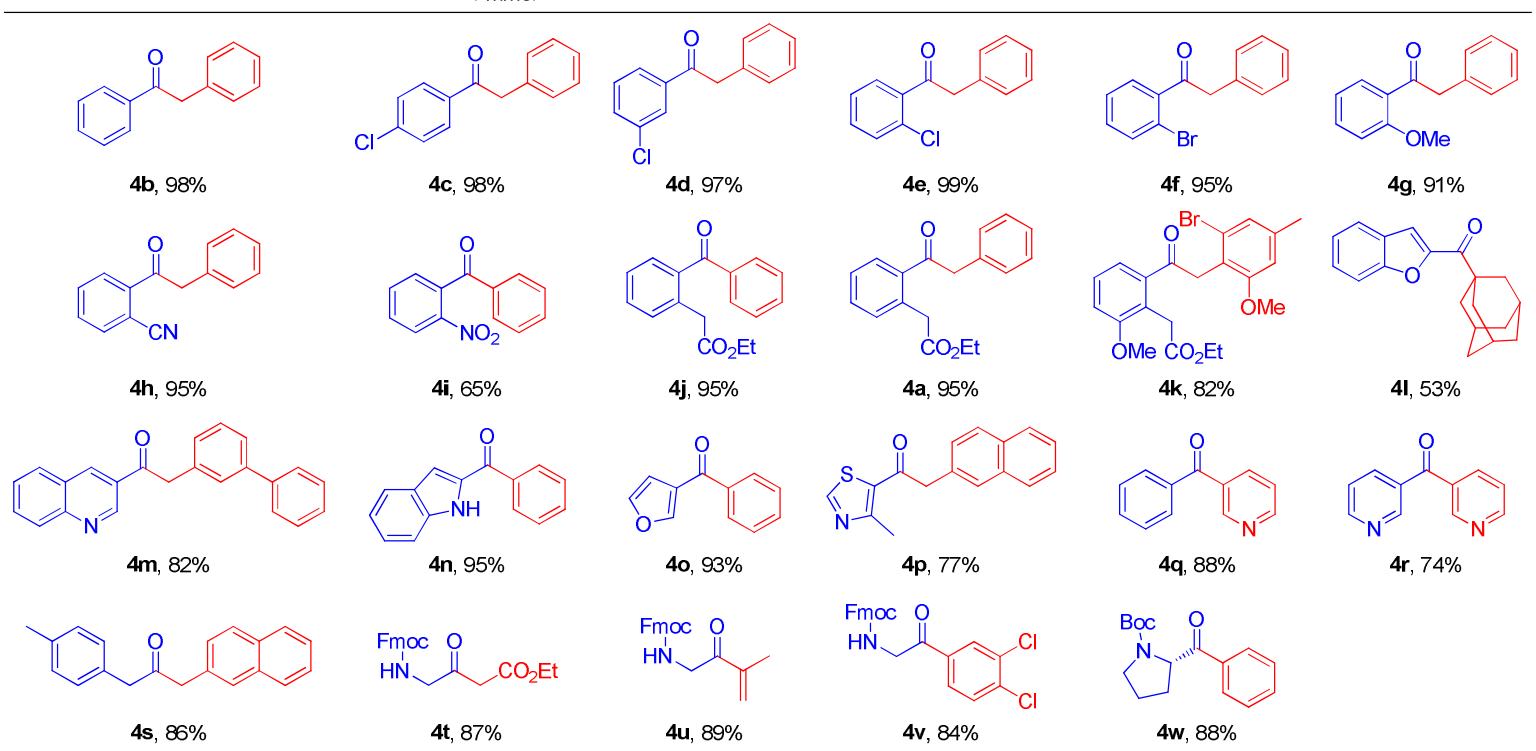

${ }^{a}$ Reaction conditions: Thioester $3(1 \mathrm{mmol}), \mathrm{PdCl}(\mathrm{Ph})\left(\mathrm{PPh}_{3}\right)_{2}(0.1 \mathrm{~mol} \%), \mathrm{R}^{2} \mathrm{ZnBr} 6$ (1.5 mmol in THF), toluene (2.5 mL), rt, 1-3 h.

\section{Scheme 2. Scale-Up (a) and in situ generation of $\operatorname{PdCl}(\mathbf{P h})\left(\mathrm{PPh}_{3}\right)_{2}(\mathrm{~b})$}

a)

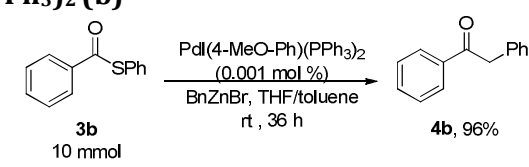

b)

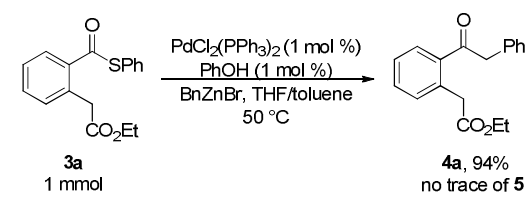

Interestingly, POxAP can also be generated in situ starting from $\mathrm{PdCl}_{2}\left(\mathrm{PPh}_{3}\right)_{2}$. Indeed, in 2006, Yasuda et al. reported that $\mathrm{PdCl}_{2}\left(\mathrm{PPh}_{3}\right)_{2}$ reacts with phenolate to afford $\mathrm{PdCl}(\mathrm{Ph})\left(\mathrm{PPh}_{3}\right)_{2}$ in a low yield $(\approx 10 \%) \cdot{ }^{15}$ Moreover, through the use of equimolar amounts of $\mathrm{PdCl}_{2}\left(\mathrm{PPh}_{3}\right)_{2}$ and $\mathrm{PhOH}$ in the presence of organozinc reagents, the POxAP $\mathrm{PdCl}(\mathrm{Ph})\left(\mathrm{PPh}_{3}\right)_{2}$ was generated in situ, as confirmed by NMR spectroscopy (see SI), and compound 4a was obtained in $94 \%$ yield (Scheme 2b), without any trace of naphthalenediol 5.

With the efficient precatalyst POxAP in hand, we attempted to complete the synthesis of the IPK precursor (Scheme 3) following the strategy proposed in Figure 1. Starting from 2,5-dimethylphenol, the perbromination of positions 3,4 , and 6 , followed by the debromination of positions 4 and 6 by $\mathrm{AlCl}_{3}$, led to the desired 3-bromo-2,5-dimethylphenol. Following a subsequent 0 -methylation step, 7 was obtained in a $74 \%$ overall yield (3 steps). Radical bromination of the methyl group at position 2 then gave organozinc 6c, which was stored in THF. Subsequently, 2bromo-3-methoxybenzoic acid was coupled to ethyl acetoacetate in the presence of a catalytic amount of copper
Scheme 3. Total synthesis of the IPK precursor 1
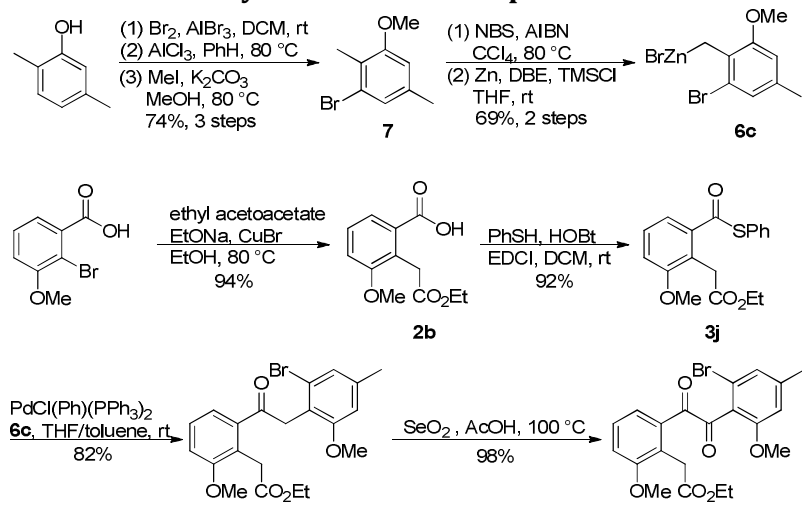

$4 \mathbf{k}$

8b

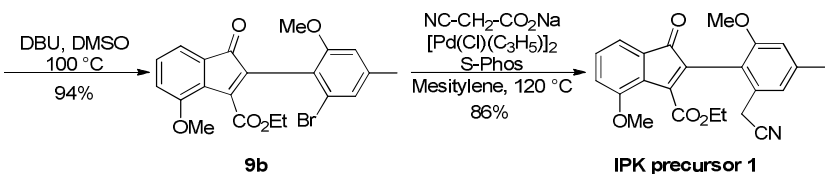

bromide. While sodium ethanolate is required for the copper-mediated coupling reaction, it also promoted an in situ deacetylation to afford $\mathbf{2 b}$ in a $94 \%$ yield. Following formation of the thioester $\mathbf{3 j}$ under standard conditions, a Fukuyama CCR was performed with organozinc $\mathbf{6 c}$ using POxAP PdCl(Ph)(PPh $)_{2}$ to give 4k in $82 \%$ yield, which was oxidized by $\mathrm{SeO}_{2}$ in $\mathrm{AcOH} .{ }^{16}$ Several conditions were then attempted for the subsequent cyclization. While TEA in hot ethanol produced 9a (Table 1), the unsubstituted analog of $\mathbf{9 b}$, the steric hindrance imparted by both aromatic rings of $\mathbf{8 b}$ prevented the formation of $\mathbf{9 b}$ itself. Several conditions were examined (see SI), but only the use of DBU in hot DMSO led to indanone $\mathbf{9 b}$ in an excellent yield. Finally, a palladium-catalyzed cyanation reaction led to the desired 
IPK precursor 1. This compound was synthesized over 11 steps and in an overall yield of $29 \%$. This compares to a $3 \%$ overall yield from 16 steps as reported previously. ${ }^{2 \mathrm{e}}$

In conclusion, we demonstrated that the POxAPs of generic formula $\mathrm{PdX}(\mathrm{Ar})\left(\mathrm{PPh}_{3}\right)_{2}$, prepared from the oxidative addition of $\mathrm{Pd}(0)$ with $\mathrm{ArX}$, constituted efficient $\mathrm{Pd}(\mathrm{II})$ precatalysts. Indeed, these bench stable POxAPs could be employed in particularly low quantities $(0.001 \mathrm{~mol} \%)$ to perform Fukuyama CCRs and generate a large diversity of ketones. This efficacy was demonstrated through the development of a convenient route to IPK. The use of these POxAP are not limited to the Fukuyama CCR, and their efficacies in other palladium-catalyzed CCRs are currently under investigation.

\section{ASSOCIATED CONTENT}

\section{Supporting Information}

The Supporting Information is available free of charge on the ACS Publications website.

Full experimental details; ${ }^{1} \mathrm{H}$ and ${ }^{13} \mathrm{C}$ NMR spectra (doc)

\section{AUTHOR INFORMATION}

\section{Corresponding Author}

* phone: +33 (0)3 68854 130; email: fbihel@unistra.fr.

\section{Author Contributions}

The manuscript was written through contributions of all authors.

Notes

The authors declare no competing financial interest.

\section{ACKNOWLEDGMENT}

We thank Dr M. Gulea (UMR7200) and Dr G Blond (UMR7200) for assistance in the preparation of this manuscript. We gratefully acknowledge the Ministry of Education of the P. R. China for financial support of this work.

\section{REFERENCES}

(1) (a) Ito, S.; Matsuya, T.; Ōmura, S.; Otani, M.; Nakagawa, A. J. Antibiot. (Tokyo). 1970, 23, 315-317. (b) Seaton, P. J.; J.Gould, S. J. Antibiot. (Tokyo). 1989, 42, 189-197. (c) Herzon, S. B.; Woo, C. M. Nat. Prod. Rep. 2012, 29, 87-118.

(2) (a) Hauser, F. M.; Zhou, M. J. Org. Chem. 1996, 61, 5722-5722. (b) Proteau, P.J.; Li, Y.; Chen, J.; Williamson, R. T.; Gould, S. J.; Laufer, R. S.; Dmitrienko, G. I. J. Am. Chem. Soc. 2000, 122, 8325-8326. (c) Laufer, R. S.; Dmitrienko, G. I. J. Am. Chem. Soc. 2002, 124, 1854-
1855. (d) Birman, V. B.; Zhao, Z.; Guo, L. Org. Lett. 2007, 9, 12231225. (e) Liu, W.; Buck, M.; Chen, N.; Shang, M.; Taylor, N. J.; Asoud, J.; Wu, X.; Hasinoff, B. B.; Dmitrienko, G. I. Org. Lett. 2007, 9, 29152918.

(3) Tokuyama, H.; Yokoshima, S.; Yamashita, T.; Fukuyama, T. Tetrahedron Lett. 1998, 39, 3189-3192.

(4) Velcicky, J.; Bodendorf, U.; Rigollier, P.; Epple, R.; Beisner, D. R.; Guerini, D.; Smith, P.; Liu, B.; Feifel, R.; Wipfli, P.; Aichholz, R.; Couttet, P.; Dix, I.; Widmer, T.; Wen, B.; Brandl, T. J. Med. Chem. 2018, 61, 865-880.

(5) (a) Kunchithapatham, K.; Eichman, C. C.; Stambuli, J. P. Chem. Commun.(London) 2011, 47, 12679-12681. (b) Cherney, A. H.; Reisman, S. E. Tetrahedron 2014, 70, 3259-3265. (c) Shimizu, T.; Seki, M. Tetrahedron Lett. 2002, 43, 1039-1042. (d) Cardellicchio, C.; Fiandanese, V.; Marchese, G.; Ronzini, L. Tetrahedron Lett. 1985, 26, 3595-3598.

(6) For reviews: (a) Valente, C.; Çalimsiz, S.; Hoi, K. H.; Mallik, D.; Sayah, M.; Organ, M. G. Angew. Chem., Int. Ed. 2012, 51, 3314-3332. (b) Bruno, N. C.; Tudge, M. T.; Buchwald, S. L. Chem. Sci. 2013, 4, 916-920.

(7) (a) Organ, M. G.; Avola, S.; Dubovyk, I.; Hadei, N.; Kantchev, E. A. B.; O'Brien, C. J.; Valente, G. Chem. - Eur. J. 2006, 12, 4749-4755. (b) Valente, C.; Belowich, M. E.; Hadei, N.; Organ, M. G. Eur. J. Org. Chem. 2010, 23, 4343-4354. (c) Yang, Y.; Oldenhuis, N. J.; Buchwald, S. L. Angew. Chem., Int. Ed. 2013, 52, 615-619. (d) Haas, D.; Hammann, J. M.; Greiner, R.; Knochel, P. ACS Catal. 2016, 6, 1540-1552.

(8) Ingoglia, B. T.; Buchwald, S. L. Org. Lett. 2017, 19, 2853-2856.

(9) (a) Jutand, A.; Négri, S.; Principaud, A. Eur. J. Inorg. Chem. 2005, 631-635. (b) Carrow, B. P.; Hartwig, J. F. J. Am. Chem. Soc. 2011, 133, 2116-2119. (c) Grushin, V. V. Organometallics 2000, 19, 18881900.

(10) Schoenberg, A.; Heck, R. F. J. Org. Chem. 1974, 39, 3327-3331.

(11) Fauvarque, J. F.; Jutand, A. J.Organomet. Chem. 1979, 177, 273281.

(12) Sekiya, A.; Ishikawa, N. J.Organomet. Chem. 1976, 118, 349354.

(13) Flemming, J. P.; Pilon, M. C.; Borbulevitch, O. Y.; Antipin, M. Y.; Grushin, V. V. Inorg. Chim. Acta 1998, 280, 87-98.

(14) For recent examples of other recent strategies to form ketones, see: (a) Halima, T. B.; Zhang, W.; Yalaoui, I.; Hong, X.; Yang, Y. F.; Houk, K. N.; Newman, S. G. J. Am. Chem. Soc. 2017, 139, 13111318. (b) Zhang, M.; Xie, J.; Zhu, C. Nat. Commun. 2018, 9, 1-10. (c) Xia, Y.; Wang, J.; Dong, G. J. Am. Chem. Soc. 2018, 140, 5347-5351. (d) Kinney, R. G.; Tjutrins, J.; Torres, G. M.; Liu N. J.; Kulkarni O.; Arndtsen B. A. Nat. Commun. 2018, 10, 193-199. (e) Fujii T.; Oki Y.; Nakada M. Tetrahedron Lett. 2018, 59, 10, 882-886. (f) Carlson A. S.; Calcanas C.; Brunner R. M.; Topczewski J. J. Org. Lett. 2018, 20, 6, 1604-1607.

(15) Yasuda, H.; Maki, N.; Choi, J. C.; Abla, M.; Sakakura, T. J. Organomet. Chem. 2006, 691, 1307-1310.

(16) Klein, D. J.; Modarelli, D. A.; Harris, F. W. Macromolecules (Washington, DC, U. S.) 2001, 34, 2427-2437. 